\title{
Arachnoid Cyst Causing Depression and Neuropsychiatric Symptoms: a Case Report
}

\author{
M Shettar, R Karkal, R Misra, A Kakunje, VV Mohan Chandran, RD Mendonsa
}

\begin{abstract}
Arachnoid cysts are benign space-occupying brain lesions that contain cerebrospinal fluid. Most cases are congenital in origin, caused by failed fusion of the arachnoid membrane early in fetal development. Cases are often incidentally detected on neuroimaging; however, rarely patients present with neuropsychiatric manifestations when cysts expand and cause a midline shift, compression of nearby brain tissue or cerebrospinal fluid compartments or both. We report a case of a 56-year-old woman with no past history or family history of psychiatric illness who developed acute-onset right-sided weakness, depressive symptoms, and other neuropsychiatric deficits. A diagnosis of organic mood disorder caused by an arachnoid cyst was made. Her symptoms and neuropsychiatric deficits remitted after cyst marsupialisation by open craniotomy. Therefore, it is important to investigate the organic aetiology in elderly patients who present with simultaneous mood disorder and cognitive dysfunction.
\end{abstract}

Key words: Arachnoid cysts; Depression

\begin{abstract}
Dr Manoj Shettar, MBBS, Department of Psychiatry, Yenepoya Medical College and Hospital, Mangalore, India.

Dr Ravichandra Karkal, MD, Department of Psychiatry, Yenepoya Medical College and Hospital, Mangalore, India.

Dr Rajneesh Misra, Department of Neurosurgery, Yenepoya Medical College and Hospital, Mangalore, India.

Dr Anil Kakunje, DPM, MD, Department of Psychiatry, Yenepoya Medical College and Hospital, Mangalore, India.

Dr VV Mohan Chandran, DPM, MD, Department of Psychiatry, Yenepoya Medical College and Hospital, Mangalore, India.

Dr Rohan Dilip Mendonsa, MD, Department of Psychiatry, Yenepoya Medical College and Hospital, Mangalore, India.
\end{abstract}

Address for correspondence: Dr Manoj Shettar, Department of Psychiatry, Yenepoya Medical College and Hospital, Mangalore, India.

Email:shettarmanoj@gmail.com

Submitted: 29 December 2016; Accepted: 18 December 2017

\section{Introduction}

Arachnoid cysts are benign space-occupying brain lesions that contain cerebrospinal fluid and account for $1 \%$ of all intracranial space-occupying lesions. ${ }^{1}$ Most of these are primary cysts arising from congenital defects of cortical formation or as anomalies in the leptomeninges, ${ }^{2}$ whereas secondary cysts arise from trauma, infection, or neoplasia. Enlargement of arachnoid cysts can be caused by fluid secretion from ependymal cells, fluid ingress secondary to an osmotic gradient, trapping of fluid by a ball/valve mechanism, ${ }^{3}$ and strenuous venous pulsation produced during Valsalva manoeuvres. ${ }^{4}$ Arachnoid cysts are more common in males than females with a prevalence ratio of $3: 1 .^{5}$

Tumours in the frontal lobe may result in apathy, disinhibition, euphoria, depression, dementia, lack of concern, poor judgement, disorientation, poor attention and concentration, personality changes, weakness of contralateral limbs, motor aphasia, and urinary incontinence. ${ }^{6}$ Damage to the ventromedial prefrontal cortex leads to impulsivity. ${ }^{7}$ Prefrontal lesions cause deficits in searching for spatiotemporal information. ${ }^{8}$ Lesions in the cerebral falx that involve bilateral medial aspects of the frontal lobe result in attention deficits in complex tasks. ${ }^{9}$ Vascular dementia in the frontal lobe results in dementia, lack of volition, emotional lability, small-stepped gait, dysarthria, and urinary incontinence. ${ }^{10}$ Left frontal astrocytoma can cause symptoms such as anxiety and obsessive behaviour, ${ }^{11}$ as well as faecal incontinence and epileptic attacks. ${ }^{12}$ Frontal lobe tumours on the right side may result in euphoria, poor attention and concentration, and poor judgement. ${ }^{13}$ Damage to structures functionally connected to the orbitofrontal cortex in the right hemisphere is associated with secondary mania. ${ }^{14}$ Pathology in the temporal lobe can cause pure amnesia, ${ }^{15}$ psychoses such as auditory hallucination, selfinjurious behaviour, ${ }^{16}$ and schizophrenia. ${ }^{17}$ Damage to the parietal lobe may cause schizophrenia-like psychosis with severe paranoid delusions and delusions of reference, auditory hallucinations, ${ }^{18}$ and conversion. ${ }^{19}$ Occipital lobe tumours may cause visual hallucinations, auditory hallucinations, abnormalities in smell and taste, and increased intracranial pressure..$^{20}$

\section{Case Presentation}

In October 2014, a 56-year-old woman, who was illiterate and widowed, presented to the Department of Psychiatry at Yenepoya Medical College and Hospital, Mangalore, India. She had a 45-day history of weakness on her right-side body and face, slurring of speech, memory disturbances, 
low mood and loss of interest in work, frequent crying spells, social withdrawal, motor restlessness, poor selfcare, reduced appetite, insomnia, irritability, disinhibited behaviour, and urinary incontinence.

On mental status examination, she had poor eye contact, dysphoric facial expression, and reduced speech rate and volume. Her thinking was retarded. She expressed feelings of worthlessness, hopelessness, and death wishes. Cognitive function tests were conducted (Table). The patients had perseveration in all frontal lobe tests and impairment in all parietal lobe tests. Temporal lobe tests showed that her immediate and recent memory was impaired, and she had a concrete level of thinking but poor insight. Both social and personal judgement was impaired.

Computed tomography and magnetic resonance imaging of her head showed a well-defined cystic lesion with a wall and septation within the left frontal lobe (Figure).

The patient was treated with sertraline with dose titrated to $100 \mathrm{mg}$ in 3 weeks and she underwent cyst marsupialisation by open craniotomy. The cyst showed presence of pale white membranous tissue. Microscopically, the cyst wall contained fibrocollagenous tissue and was lined by a single layer of uniform flat cells, suggestive of arachnoid cyst. Fluid cytology showed few red blood cells, occasional degenerating inflammatory cells, and no malignant cells.

Postoperatively, the patient's recovery was uneventful, and her symptoms gradually resolved over 45 days of follow-up.

\section{Discussion}

In our patient, the arachnoid cyst was most likely congenital in origin because there was no history of head trauma. The recent cyst enlargement might have led to the manifestation of symptoms. Because there was no history of stressors, family history of mood disorders, and the age of onset was not typical of depression, a diagnosis of organic depressive disorder (International Classification of Diseases 10 code: F 06.32) caused by an arachnoid cyst was made. The patient's depressive symptoms began almost simultaneously with other neuropsychiatric symptoms. Thus, we ruled out stress secondary to the disability and knowing of the neurosurgical diagnosis.

Like other patients with frontal lobe lesions, our patient presented with mild weakness, cognitive deficits, disinhibited behaviour, urinary incontinence, and depression. This is consistent with a case report that described associations of right frontal lobe lesions with euphoria, and left frontal lobe lesions with depression and abulia. ${ }^{21}$ This laterality is based on the phenomenon of mood elevation when the left prefrontal cortex is activated. Thus, a left prefrontal lesion leads to depression. In addition, cognitive dysfunction occur more commonly with left frontal lobe lesions than right frontal lesions. Although our patient was treated with sertraline, significant improvement in neuropsychiatric symptoms occurred only after cyst decompression surgery, similar to previous reports in the literature. ${ }^{22-24}$

Table. Cognitive function test results of the patient.

\begin{tabular}{|c|c|c|c|c|}
\hline Cognitive function test & Preoperative & Postoperative & 15-day follow-up & 45-day follow-up \\
\hline $\begin{array}{l}\text { Frontal lobe test } \\
\text { Fist-palm-side test } \\
\text { Fist-ring test } \\
\text { Reciprocal co-ordination test } \\
\text { Set shifting } \\
\text { Set shifting drawing }\end{array}$ & $\begin{array}{l}\text { Perseveration + } \\
\text { Perseveration + } \\
\text { Perseveration + } \\
\text { Perseveration + } \\
\text { WMW I.Mmmm }\end{array}$ & $\begin{array}{l}\text { Perseveration } \downarrow \\
\text { Perseveration } \downarrow \\
\text { Perseveration } \downarrow \\
\text { Perseveration } \downarrow \\
\square \square / 77\end{array}$ & $\begin{array}{l}\text { Greatly } \downarrow \\
\text { Greatly } \downarrow \\
\text { Greatly } \downarrow \\
\text { Greatly } \downarrow \\
\triangle W N D W \\
\end{array}$ & $\begin{array}{l}\text { Normal } \\
\text { Normal } \\
\text { Normal } \\
\text { Normal }\end{array}$ \\
\hline $\begin{array}{l}\text { Parietal lobe test } \\
\text { Graphaesthesia } \\
\text { 2-point discrimination test } \\
\text { Test for constructional ability } \\
\text { Drawing on command }\end{array}$ & $\begin{array}{l}\text { Negative } \\
\text { Negative } \\
\text { Negative } \\
\text { Negative }\end{array}$ & $\begin{array}{c}\text { Negative } \\
\text { Negative } \\
\text { Positive } \\
\text { Positive }\end{array}$ & $\begin{array}{l}\text { Positive } \\
\text { Positive } \\
\text { Positive } \\
\text { Positive }\end{array}$ & $\begin{array}{l}\text { Positive } \\
\text { Positive } \\
\text { Positive } \\
\text { Positive }\end{array}$ \\
\hline $\begin{array}{l}\text { Temporal lobe test } \\
\text { Immediate memory } \\
\text { Recent memory } \\
\text { Abstract ability: similarities and } \\
\text { proverb interpretation }\end{array}$ & $\begin{array}{l}\text { Impaired } \\
\text { Impaired } \\
\text { Concrete }\end{array}$ & $\begin{array}{c}\text { Intact } \\
\text { Intact } \\
\text { Abstract }\end{array}$ & $\begin{array}{c}\text { Intact } \\
\text { Intact } \\
\text { Abstract }\end{array}$ & $\begin{array}{c}\text { Intact } \\
\text { Intact } \\
\text { Abstract }\end{array}$ \\
\hline Hamilton Depression Rating Scale & 21 & 6 & 5 & 5 \\
\hline
\end{tabular}



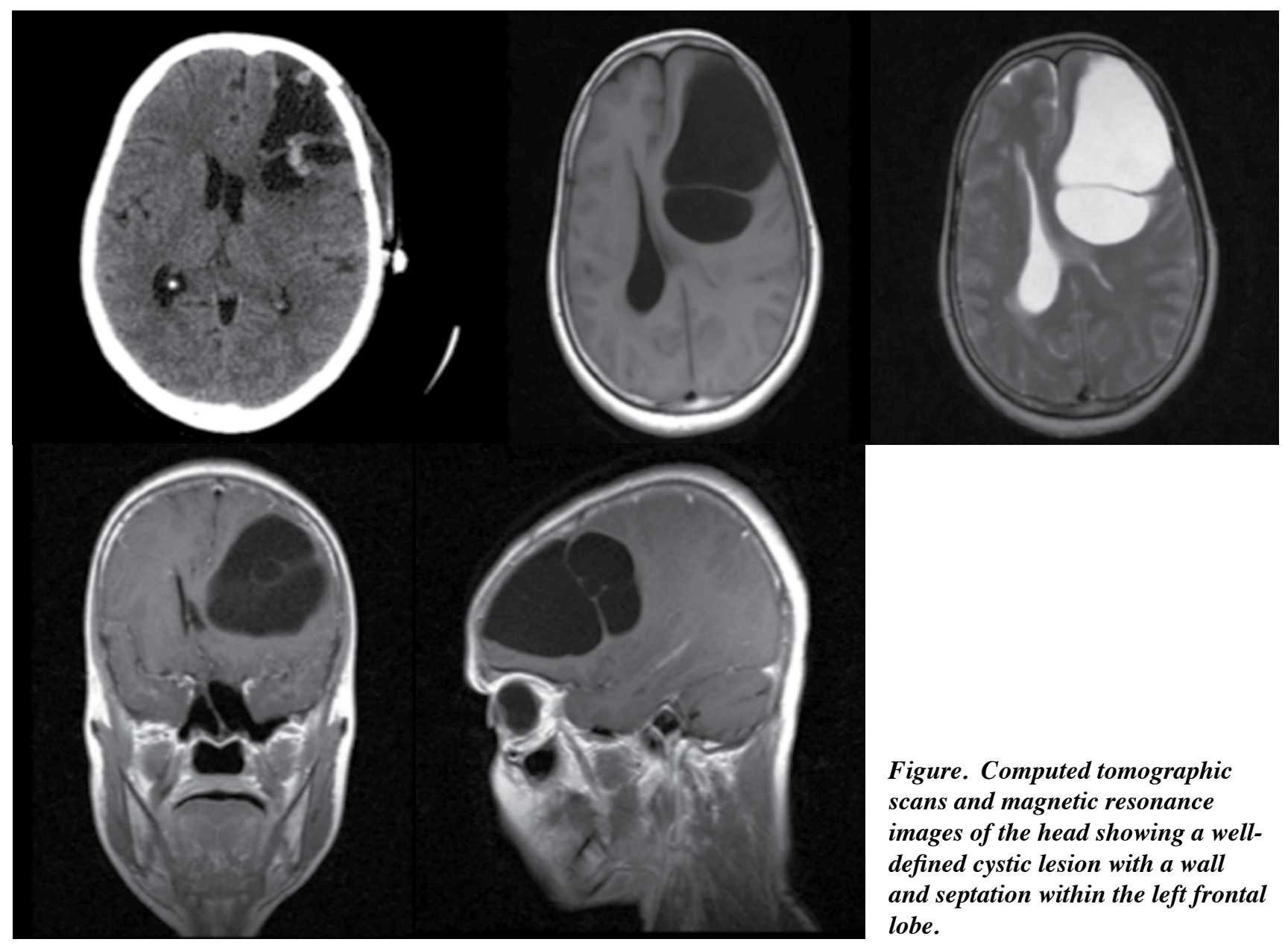

Figure. Computed tomographic scans and magnetic resonance images of the head showing a welldefined cystic lesion with a wall and septation within the left frontal lobe.

Arachnoid cysts may lead to reversible impairments in cognition, executive function, and mood (depression or mania, depending on the laterality of the lesion). Surgical intervention to decompress the cyst can achieve significant improvement of the symptoms. It is important to investigate the organic aetiology in elderly patients who present with simultaneous mood disorder and cognitive dysfunction.

\section{Declaration}

The authors have no conflicts of interest to disclose.

\section{References}

1. Gosalakkal JA. Intracranial arachnoid cysts in children: a review of pathogenesis, clinical features, and management. Pediatr Neurol 2002;26:93-8. cross re

2. Hayashi T, Shirouzu T, Miyagi J, Kawai K, Anegawa S, Kuramoto S. Temporal arachnoid cyst. Kurume Med J 1979;26:57-62. Eross re

3. Dyck P, Gruskin P. Supratentorial arachnoid cysts in adults: a discussion of two cases from a pathophysiologic and surgical perspective. Arch Neurol 1977;34:276-9. cross re

4. Williams B, Guthkelch AN. Why do central arachnoid pouches expand? J Neurol Neurosurg Psychiatry 1974;37:1085-92. Eross ref

5. Wester K. Gender distribution and sidedness of middle fossa arachnoid cysts: a review of cases diagnosed with computed imaging. Neurosurgery 1992;31:940-4. Eross re

6. Jefferson G. Tumours of the frontal lobe. Postgrad Med J 1950;26:13340 Eross re

7. Bechara A, Damasio AR, Damasio H, Anderson SW. Insensitivity to future consequences following damage to human prefrontal cortex. Cognition 1994;50:7-15. Eross re

8. Schacter DL. Memory, amnesia, and frontal lobe dysfunction. Psychobiology 1987;15:21-36.

9. Leimkuhler ME, Mesulam MM. Reversible go-no go deficits in a case of frontal lobe tumor. Ann Neurol 1985;18:617-9. Eross ref

10. Ishii $\mathrm{N}$, Nishihara $\mathrm{Y}$, Imamura $\mathrm{T}$. Why do frontal lobe symptoms predominate in vascular dementia with lacunes? Neurology 1986;36:340-5. Eross ret

11. John G, Eapen V, Shaw GK. Frontal glioma presenting as anxiety and obsessions: a case report. Acta Neurol Scand 1997;96:194-5. cross re

12. Maurice-Williams RS. Micturition symptoms in frontal tumours. J Neurol Neurosurg Psychiatry 1974;37:431-6. Eross rel 13.

Belyi BI. Mental impairment in unilateral frontal tumours: role of the laterality of the lesion. Int J Neurosci 1987;32:799-810. Eross re

14. Starkstein SE, Boston JD, Robinson RG. Mechanisms of mania after brain injury. 12 case reports and review of the literature. J Nerv Ment Dis 1988; 176:87-100. Eross re

15. Umemura A, Yamada K, Masago A, Tanigawa M, Nakaaki S, Hamanaka 
T. Pure amnesia caused by bilateral temporal lobe astrocytoma: case report. Neurol Med Chir (Tokyo) 1997;37:556-9. Eross re

16. Krayem BH, Dunn NR, Swift RG. Psychosis after right temporal lobe tumor resection and recurrence. J Neuropsychiatry Clin Neurosci 2014;26:E47. cross ret

17. Bunevicius A, Deltuva VP, Deltuviene D, Tamasauskas A, Bunevicius R. Brain lesions manifesting as psychiatric disorders: eight cases. CNS Spectr 2008;13:950-8. cross ret

18. Canuet L, Ikezawa K, Ishii R, Aoki Y, Iwase M, Takeda M. Schizophrenia-like psychosis associated with right-parietal meningioma. J Neuropsychiatry Clin Neurosci 2011;23:E36. Eross re

19. Ramasubbu R. Conversion sensory symptoms associated with parietal lobe infarct: case report, diagnostic issues and brain mechanisms. J Psychiatry Neurosci 2002;27:118-22.
20. Allen IM. A clinical study of tumours involving the occipital lobe. Brain 1930;53:194-243. Eross ret

21. Madhusoodanan S, Danan D, Moise D. Psychiatric manifestations of brain tumors: diagnostic implications. Expert Rev Neurother 2007;7:343-9. cross re

22. Starkstein SE, Robinson RG. Neuropsychiatric aspects of stroke. In: Coffey CE, Cummings JL, Lovell MR, Pearlson GD, Editors. Textbook of Geriatric Neuropsychiatry. Washington, DC: American Psychiatric Press; 1994: 457-77.

23. Soukup VM, Patterson J, Trier TT, Chen JW. Cognitive improvement despite minimal arachnoid cyst decompression. Brain Dev 1998;20:589-93. Eross re

24. Harsh GR 4th, Edwards MS, Wilson CB. Intracranial arachnoid cysts in children. J Neurosurg 1986;64:835-42 eross re 